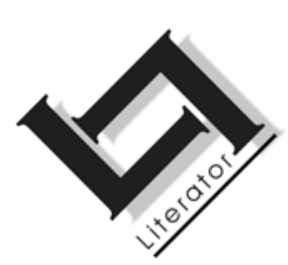

\title{
Om (somtyds) lig en aandagtig te reis: mistici in drie romans van Lettie Viljoen/ Ingrid Winterbach ${ }^{1}$
}

\author{
L. Foster \\ Departement Afrikaans en Nederlands \\ Universiteit van Stellenbosch \\ STELLENBOSCH \\ E-pos: buitelander@yahoo.co.uk
}

Let's be pragmatic.

Saints, monks mystics - their faith works.

So what if they're nuts?

(David Bader, 2005:85.)

\begin{abstract}
Traveling light and attentively (on occasion): mystics in three novels by Lettie Viljoen/Ingrid Winterbach

By means of references to mystics, the author Lettie Viljoen/ Ingrid Winterbach creates a framework within which characters who exhibit mystic tendencies - namely Fonny Alexander and Boetie Kareltjie ("Buller se plan") and the master ("Landskap met vroue en slang") - can be compared. This matrix activates a number of issues: the place of women within a religious-cultural system and the power they wield within such a system by resorting to mysticism, engagement with existing systems of authority and the possibility of exerting power by withdrawing from such systems, the traditional opposition between physicality and spiritual purity, and the issue of martyrdom. Against this backdrop Fonny's obliteration of her own identity in an
\end{abstract}

$1 \quad$ Hierdie artikel is gebaseer op Hoofstuk 4 van my tesis, Marginale en liminale karakters in die werk van Lettie Viljoen/Ingrid Winterbach: sosiale kommentaar en die ondermyning van grense, ingelewer ter gedeeltelike voldoening aan die vereistes vir die graad van Magister in die Lettere en Wysbegeerte aan die Universiteit van Stellenbosch. My dank aan my studieleier, prof. Louise Viljoen, vir haar waardevolle raad. 
attempt to cope with trauma is contrasted with the master's approach of experiencing and accepting change and attempting to learn from it. Ultimately it is argued that there is an attempt to reject a type of mysticism that pretends to offer power to its proponents while actually disempowering them.

\section{Opsomming}

\section{Om (somtyds) lig en aandagtig te reis: mistici in drie romans van Lettie Viljoen/Ingrid Winterbach}

Deur middel van verwysings na mistici, skep die outeur Lettie Viljoen/Ingrid Winterbach 'n raamwerk waarteen karakters wat mistieke neigings openbaar - soos Fonny Alexander en Boetie Kareltjie ("Buller se plan") en die meester ("Landskap met vroue en slang") - vergelyk kan word. Hierdie raamwerk aktiveer 'n aantal kwessies: die plek van vroue binne 'n godsdienstigkulturele stelsel en die mag wat hulle binne sodanige stelsel kan uitoefen deur hulle tot mistisisme te wend, hulle betrokkenheid by bestaande gesagstelsels en die moontlike uitoefening van mag deur uit sodanige stelsels te onttrek, die tradisionele opposisie tussen liggaamlikheid en spirituele reinheid en ook die kwessie van martelaarskap. Teen hierdie agtergrond word Fonny se vernietiging van haar eie identiteit in 'n poging om trauma te verwerk, gekontrasteer met die meester se benadering, waarin verandering ervaar en aanvaar word en daar pogings is om daaruit te leer. Uiteindelik word geargumenteer dat daar 'n poging is om 'n tipe mistisisme te verwerp wat voorgee dat dit mag aan die navolgers daarvan bied terwyl dit hulle eintlik ontmagtig.

\section{Inleidende opmerkings}

Lettie Viljoen/Ingrid Winterbach se werk bevraagteken en ondermyn dikwels die patriargale bestel. Hierdie artikel sal aandag skenk aan die wyse waarop hierdie ondermyning en bevraagtekening bewerkstellig word deurdat Viljoen/Winterbach mistici oor wie se bestaan daar 'n mate van geskiedkundige sekerheid is en mistici wat slegs literêre karakters is, insluit in haar werk. $\mathrm{Na}$ 'n aantal inleidende opmerkings oor die posisie van vroue binne die Christelike bestel, waaruit Viljoen/Winterbach die meeste van haar "heiliges" leen, sal 'n raamwerk uiteengesit word waarbinne vroulike seksualiteit, sensualiteit, geestelikheid en magsposisies in heroënskou geneem word. Kwessies rondom liggaamlikheid, martelaarskap en die beheer oor ' $n$ individu se liggaam en gees is ter sprake in hierdie afdeling. In die derde afdeling sal die karakters in Viljoen/Winterbach 
se werk wat as mistici beskryf sou kon word, 2 bespreek word. Die artikel eindig met 'n aantal opsommende opmerkings.

Mistici speel geensins 'n rol in Lettie Viljoen se vroeë romans nie. Dit is eers in haar laaste twee romans, Karolina Ferreira en Landskap met vroue en slang geskryf onder hierdie skuilnaam en die eerste onder haar eie naam van Ingrid Winterbach Buller se plan dat sy verwysings na mistici en karakters wat as mistici beskryf sou kon word, insluit. Daar word grotendeels op vroue gefokus - van die mistici na wie Viljoen/Winterbach verwys, is slegs een, naamlik die heilige Ignatius Loyola, 'n man.

Deur veral vroulike mistici by haar werk te betrek, gebruik Viljoen/ Winterbach 'n ander invalshoek op belangrike temas in haar werk, naamlik die ervarings van vroue en die (mags)posisie van vroue binne die patriargale bestel. Haar aanbieding van die mistici (deur middel van verwysings na mistici oor wie se bestaan daar 'n mate van geskiedkundige sekerheid is en die gebruik van karakters wat as mistici geklassifiseer kan word) moet liefs nie gesien word as kommentaar op spesifieke godsdienstige stelsels nie, maar eerder as kommentaar op die manier waarop mense met godsdienstige stelsels omgaan.

Deur grotendeels op vroue se mistieke ervarings te fokus, vermag Viljoen/Winterbach tegelykertyd twee dinge. Eerstens fokus sy op die vrou se ervaring van die mistieke. Tweedens was (sommige gender-kritici sou sê is) daar in kerklike kringe 'n neiging om vroue en vroulikheid met liggaamlikheid te verbind, terwyl mans en manlikheid met rasionaliteit verbind is. Terselfdertyd word ook 'n verband gelê tussen spiritualiteit en manlikheid (Jantzen, 1997:47). In gevalle waar vroue wel mistici was - feitlik altyd binne kloosters - was daar dikwels grootskaalse pogings om hulle mistisisme aan bande te lê (Jantzen, 1997:158). Viljoen/Winterbach is nie besig met 'n grootskaalse herskrywing van die geskiedenis nie. Deur haar uitbeelding van karakters en deur die tipe karakters wat sy uitbeeld, bewerkstellig sy 'n klemverskuiwing en ondermyn sy die patriargale magstelsel wat eeue reeds bestaan, sowel binne die mistisisme self as in letterkunde óór die mistisisme (vgl. Jantzen, 1997:24).

2 Ter wille van bondigheid sal daar na die karakters wat op historiese figure (of figure wie se bestaan ten minste gedeeltelik deur geskiedenisbronne gestaaf word) gegrond is, as mistici of werklike mistici verwys word - hoewel hulle insluiting in 'n literêre werk (en die fiksionalisering wat daarmee gepaard gaan) hulle ook in karakters omskep. 
Die marginalisering van die vroulike mistikus is meer kompleks as wat dit aanvanklik voorkom. In Middeleeuse Europa tel vroue definitief onder die gemarginaliseerdes, en meer as in die twintigste eeu, het die vrou se klas en geletterdheid 'n belangrike (selfs bepalende) rol gespeel in die mate waartoe sy gemarginaliseer is en watter moontlikhede sy gehad het om haar nader aan die sentrum te posisioneer. Vroue wat deur hulle families in kloosters geplaas is, of wat self besluit het om hulle toevlug tot 'n klooster te neem, is oënskynlik die mees gemarginaliseerde van 'n reeds gemarginaliseerde groep. Daar moet egter onthou word dat dogters wat op 'n vroeë ouderdom na kloosters gestuur is, dikwels van welgestelde, adellike families was en dat hulle (en selfs diegene wat nie deel van die elite was nie) die moontlikheid gehad het om hulle kennis uit te brei deur blootstelling aan boeke. Indien hulle binne die magshiërargie van die klooster vordering kon maak, óf indien hulle 'n reputasie gehad het vir buitengewone vroomheid, kon hulle besonder invloedryk word. As daar in ag geneem word dat Middeleeuse Europa deur die kerk beheer is, is 'n magsposisie binne die kerk (ten spyte van die afsondering wat die lewe in 'n klooster noodwendig meegebring het) ' $n$ groot tree in die rigting van sentraliteit. 3 Vroulike mistici bevind hulself dus in 'n ambivalente posisie aansienlik meer ambivalent as manlike mistici. Enersyds is hulle (selfs binne die kerklike opset) weerhou van mag as gevolg van hulle geslag en verder is hulle tot die marge gerelegeer deur hulle isolasie in kloosters. Andersyds bied hulle affiliasie by dié belangrikste instelling in die Middeleeue hulle 'n bepaalde hoeveelheid mag en hierdie mag word uitgebrei deur hulle mistieke wedervarings. Die raamwerk wat Viljoen/Winterbach skep, moet teen hierdie historiese agtergrond, en veral teen die inherent ambivalente posisie van vroulike mistici, gekontekstualiseer word.

In die afdeling wat volg, sal aandag geskenk word aan die manier waarop Viljoen/Winterbach die ervarings van werklike mistici in haar werk inbou om 'n raamwerk te skep waarvolgens vroulike seksualiteit, sensualiteit, geestelikheid en magsposisies in heroënskou geneem word.

3 Dit is bemagtiging in die letterlike sin van die woord - die vroulike mistici het meer mag verkry. Die moderne konnotasies (veral binne die Suid-Afrikaanse konteks) waarmee die woord bemagtiging gepaard gaan, lei egter daartoe dat dit nie 'n gepaste beskrywing van die Middeleeuse situasie is nie. 


\section{Kwessies binne die raamwerk}

\subsection{Liggaamlikheid en verbeelding}

In Karolina Ferreira (Viljoen, 1993:138, 141) verwys Adelia Farber, die Suid-Amerikaanse kunstenaar, na die ervarings van sewentiende-eeuse mistici. Uit die name wat Viljoen/Winterbach gebruik, blyk dit egter dat sý, ten minste wat vroulike mistici betref, eerder fokus op sestiende-eeuse mistici. Vanaf Karolina Ferreira (Viljoen, 1993) gebruik sy ook name wat vir die leser bekend behoort te wees, met die moontlike uitsondering van die heilige Barbara (Viljoen, 1996). Sy maak dit sodoende makliker vir die leser om binne 'n bekende kennisraamwerk te funksioneer. Hieruit wil dit dus voorkom dat Viljoen/Winterbach nie minder bekende mistici onder die leser se aandag wil bring nie, maar eerder nuwe lig wil werp op diegene wat reeds bekend is, of ten minste bekend behoort te wees. Wat die mistici in haar werk betref, fokus Viljoen/Winterbach in Karolina Ferreira (1993) en Landskap met vroue en slang (1996) meer op die liggaamlike aard van vroulike mistisisme. In Buller se plan (Winterbach, 1999) word die mistisisme nie meer gesien as "'n potensiële ruimte ... waarin ['n vrou] ten minste in haar verbeelding vry kon beweeg" (Viljoen, 1993:141) nie. Soos duidelik sal blyk uit 'n bespreking van die karakter Fonny Alexander, bly die mistisisme nie die private sfeer waarin vroue se "oortredende begeerte potensieel" (Viljoen, 1993:141) gestalte kan vind nie.

In Karolina Ferreira word die klem geplaas op die vrou se mistieke ervaring tydens die Nagmaal, iets wat, volgens Adelia Farber "'n betekenisvolle omkering van menstruasie - die vroulike swakheid" is (Viljoen, 1993:138). ${ }^{4}$ Die vroulike mistikus se belewing van die Nagmaal - wat in sommige gevalle gepaard gegaan het met visioene - hou egter met meer verband as net die inversie van vroulike swakheid. Grace Jantzen (1997:210) voer aan dat "feasting, particularly eating the body and drinking the blood of Christ in the eucharist (sic), was central to women's piety". Baie vroulike mistici het slegs geleef van die Nagmaal wat hulle elke dag ontvang het en het geen ander voedsel of vloeistof ingeneem nie. 5 Jantzen bied 'n aantal

$4 \quad$ Hierdie gesprek vind plaas tydens die piekniek by die spruit (Viljoen, 1993:137) waartydens daar nie alleen oorvloedig geëet en gedrink word nie. Adelia Farber "skink vir hulle rooi wyn in die kristalglase" (Viljoen, 1993:138) en sy "breek die brood, gee vir elkeen 'n stuk" (Viljoen, 1993:139) in 'n nie-religieuse versie van die Nagmaal.

$5 \quad$ In hierdie verband skryf Jantzen (1997:208): 
verklarings hiervoor. Eerstens het die asketiese houding van baie vroulike mistici hulle die bewondering van belangrike (manlike) figure binne die kerk besorg (Jantzen, 1997:213). Tweedens kon hulle, weens hulle omgang met voedsel en die wyse waarop dit geskied het, in 'n beperkte mate beheer uitoefen oor manlike familielede of priesters (Jantzen, 1997:214). Derdens is die beheptheid wat vroulike mistici met voedsel en voeding gehad het, 'n verlenging van hulle rol as diegene wat kos op 'n daaglikse grondslag voorberei het (Jantzen, 1997:211). Die Nagmaal en die vroulike mistikus se belewing daarvan het dus in 'n mate aan hulle mag besorg wat nie beskore was vir vroue in die Middeleeue nie.

Binne die Rooms-Katolieke tradisie is die verband tussen bloed, brood en liggaam eksplisiet, maar dit wil voorkom of vroulike mistici se interpretasie van transsubstansiasie (gekoppel met die faktore wat hierbo genoem is) daartoe gelei het dat hulle spirituele ervarings anders kon wees - meer eroties gelade - as dié van manlike mistici (vgl. Jantzen, 1997:138). María de San Joseph, wat in 'n briefwisseling met die heilige Teresa van Avila betrokke was, se beskrywing van die manier waarop "die mond van haar siel die wond van Jesus gepenetreer en [sy] oorvloedig van sy warm bloed gedrink het" (Viljoen, 1993:138; kursivering - LF), bring egter 'n verdere kenmerk na vore. Die erotiese element aanwesig in die werk van vroulike mistici is nie net dié van passiwiteit soos daar oor die algemeen van vroue verwag is nie (Jantzen, 1997:43-44); die vrou speel 'n meer aktiewe rol in die proses. Dit is nie net 'n ontkenning van fallosentrisme nie, maar 'n inversie daarvan. Die vroulike mistikus approprieer die seksuele rol wat normaalweg vir mans gereserveer is, ook omdat sy haar deur haar visioene nader aan die sentrum posisioneer.

So 'n appropriasie kan egter nie gesien word as 'n negering van die fallo(go)sentrisme nie, tensy dit gepaard gaan met 'n mate van ondermyning of disrupsie. 6 Soos Jantzen (1997:52) aantoon, was dit gebruiklik om na "women of spirit" in manlike terme te verwys. Indien die vroulike mistikus slegs verander in 'n man in vroue-vorm,

A disproportionate number of women saints of the period practised fasting with such severity that scholars who have traced the motif in their lives and writings speak in terms of 'holy anorexia', with, sometimes, a doubt about whether the severity should be seen as 'holy' or as an obsessive-compulsive disorder of the personality.

$6 \quad$ Vir 'n deeglike uiteensetting van die manier waarop disrupsie en appropriasie in Karolina Ferreira funksioneer, sien Viljoen (1995). 
kan daar kwalik sprake wees van ondermyning van die (patriargale) sentrum. In Karolina Ferreira is die enigste tekens van ondermyning te bespeur in Adelia Farber se interpretasie van die mistici se dade en visioene. Sy beweer byvoorbeeld dat "[o]m Christus se bloed te drink ... 'n betekenisvolle omkering van menstruasie" is (Viljoen, 1993:138) en dat die "mistieke ervaring vir die vrou ... 'n potensiële ruimte geskep [het] waarin sy ten minste in haar verbeelding vry kon beweeg" (Viljoen, 1993:141). Die inligting wat oor die mistici (by name María de San Joseph) verstrek word, is dubbelsinnig wat die ondermynende aard daarvan betref. In Landskap met vroue en slang blyk die situasie nie veel anders te wees nie: die heilige Teresa van Avila bly passief wanneer sy "met die pyl van die liefde deurboor word" (Viljoen, 1996:31).

Wat egter wél as ondermynend van die (patriargale) sentrum gesien kan word, is dat die vroulike mistici oor die algemeen almal alleen is wanneer hulle mistieke ervarings het. Enersyds is dit heel voor die hand liggend: diegene wat hulle toetrede maak tot 'n religieuse orde het meer geleentheid om hulself af te sonder van ander om sodoende mistieke ervarings alleen te beleef. Andersyds is dit belangrik dat dit vroue is wat hierdie ervarings alleen beleef - oënskynlik buite die bereik en beheer van manlike figure. Waar hulle binne die normale sosiale konteks omring sou wees deur familielede en gemoeid sou wees met hulle versorging én hulle identiteit ten volle bepaal sou word deur hulle sosiale rol, het hulle hier die geleentheid om in "ekstatiese eensaamheid" (Viljoen, 1996:31) mistieke ervarings te beleef. Wat nog belangriker is, is dat hierdie ervarings 'n sterk erotiese element bevat wat sonder die aanwesigheid van 'n man geskied - binne die Christelike tradisie word die godheid as manlik verpersoonlik, maar binne dieselfde tradisie word dit ook nie as gepas beskou om eroties-gelade kontak met die godheid te hê nie. Die vernaamste "bestaansrede" van die vrou, naamlik dat sy daar is om aan die man se seksuele behoeftes te voldoen en om kinders te baar (soos verwoord in Genesis), word sodoende genegeer. Die vrou is ten tyde van mistieke gewaarwordings op haar eie, maar tog word sy "deur die pyl van die liefde verwond" (Viljoen, 1996:75).

Dat hierdie verwonding slegs in die "verbeelding" (Viljoen, 1993:141) van die vroulike mistikus geskied, is nie noodwendig ' $n$ bevestiging van die mag van die patriargale sentrum nie. Dit is eerder 'n ondermyning daarvan, aangesien vroue nie volgens Middeleeuse denke veronderstel was om in staat tot enigiets meer as liggaamlike luste en liste te wees nie. Dat die vroulike mistikus eerstens 'n verbeel- 
ding het en tot denke in staat is, en tweedens in staat is om haar erotiese gevoelens nie fisiek nie maar intellektueel te kan uitleef, is 'n ondermyning van die heersende denke oor die vrou en oor vroulike seksualiteit.

Botha (1995:7) sien hierdie "uiteensetting van die mistieke ervaring ... as uitbreiding van die ruimte van die vrou". Sy sien dit ook as "grensoorskryding, transformasie" (Botha, 1995:7). Soos duidelik sal blyk in die volgende onderafdeling, word die ekstatiese hoogtes wat vroulike mistici bereik, gebalanseer deur ontsettende laagtepunte van angs en pyn. Sodanige ervarings is natuurlik alles behalwe bevrydend of ondermynend.

\subsection{Martelaarskap}

Byna aan die einde van Landskap met vroue en slang kom daar 'n verwysing voor wat 'n klemverskuiwing in Viljoen/Winterbach se gebruik van werklike mistici aandui. 'n Poskaart van Mara Darboven in Lena Bergh se kombuis word soos volg beskryf (Viljoen, 1996:153):

Teen die ander muur 'n poskaart van 'n religieuse prosessie in Sicilië ... die prosessie van die heilige Barbara (beskermheilige van begrafnisse); teelaarde van die Mafia, het Mara agterop geskryf.

Die heilige Teresa van Avila en María de San Joseph (en ook die heilige Ignatius Loyola) behoort tot die "kanon" van mistici. Daar is geen twyfel omtrent hulle bestaan nie en hulle het 'n mate van invloed binne die kerk gehad. Hierteenoor word die waarheid van die heilige Barbara se verhaal bevraagteken (Kirsch, 2007). Sy is ook 'n martelaar wat, volgens Middeleeuse legendes, gefolter is en deur haar eie pa onthoof is (Kirsch, 2007). Deur hierdie verwysing na die heilige Barbara, bring Viljoen/Winterbach die donkerder sy van mistici en heiliges na vore. Daar is nie net "ekstatiese eensaamheid" (Viljoen, 1996:31) nie, maar ook geweld, bloedvergieting en dood. Hierdie punt word verder beklemtoon deur die feit dat die heilige Barbara se prosessie in Sicilie plaasvind; die "teelaarde van die Mafia" (Viljoen, 1996:153) en dat daar 'n assosiasie geskep word tussen die Mafia se geskiedenis van misdaad en geweld en die heilige Barbara.

Die heilige Barbara kom egter 'n tweede maal voor in Landskap met vroue en slang (hoewel dit chronologies voor die vorige aanhaling verskyn). In die tweede geval word die effek wat sy as heilige op ander het, veral die Ander, beklemtoon. In 'n gedeelte wat Lena oor 
duende7 lees, word beweer dat diegene wat na 'n sangeres luister wat met duende sing, "later hulle klere ritmies skeur, soos Karibiese negers saamgebondel voor 'n beeltnis van die heilige Barbara" (Viljoen, 1996:116). Hier word die heilige Barbara duidelik met die gemarginaliseerdes geassosieer én met praktyke wat definitief nie deur die kerk gesanksioneer is nie. Dat passie sowel negatiewe as positiewe konnotasies het, word aangedui deur die dubbelsinnigheid waarmee die sang en die gebeure "voor 'n beeltnis van die heilige Barbara" (Viljoen, 1996:116) beskou word. Hierdie ambivalensie kan weer teruggelei word na die heilige Barbara, wat vanweë die twyfelagtigheid van haar bestaan reeds as liminaal beskou kan word.

'n Tweede figuur, wat veral in Buller se plan 'n belangrike intertekstuele funksie vervul, is Artemesia Gentileschi, 'n sewentiende-eeuse skilder wat ook ten dele gely het as gevolg van haar pa se optrede. Gentileschi is op agtienjarige ouderdom verkrag deur Agostinho Tassi, 'n skilder en kollega van haar pa (ook 'n skilder) wat in haar pa se huis gewoon en gewerk het op Gentileschi (senior) se uitnodiging (Opfell, 1991:3; Garrard, 1989:20). Gentileschi (senior) het 'n klag van verkragting teen Tassi gelê, en in 'n poging om groter geloofwaardigheid te verleen aan haar eie getuienis, wat sterk in twyfel getrek is, het Gentileschi vrywillig foltering deur die sibille 8 ondergaan (Opfell, 1991:3; Garrard, 1989:20-1). Die saak is uiteindelik uit die hof gegooi (Garrard, 1989:22). Die saak het Gentileschi egter gestigmatiseer, en hoewel sy die slagoffer was én besondere durf getoon het, het sy nie veel openbare simpatie of steun geniet nie.

'n Derde vrou is die heilige Jeanne d'Arc of Johanna van Arkel, wat, soos die heilige Barbara, in 'n terloopse verwysing haar opwagting maak (Winterbach, 1999:49). Die heilige Jeanne d'Arc is verhoor en as ketter ter dood veroordeel deur 'n Engels-gedomineerde kerklike hof in 1431 vanweë haar betrokkenheid by die Franse leër tydens die honderdjarige oorlog. Hoewel sy nie fisies gemartel is nie, was haar verhoor sielkundig uitmergelend - in so 'n mate dat sy voor haar dood ingestem het om 'n skuldbekentenis te teken, maar later daardie bekentenis teruggetrek het. Soos die heilige Barbara, is die

$7 \quad$ The Concise Oxford verklaar duende as passie, of 'n bose gees (The Concise Oxford English Dictionary, 2002).

8 'n Folterinstrument "similar to the thumbscrew, in which metal rings around the fingers are tightened by strings" (Felleman, 2001). 
heilige Jeanne ook 'n ambivalente figuur. Sy is aanvanklik as ' $n$ held beskou, daarna as 'n ketter verbrand, in 1456 gerehabiliteer (vgl. Murray, 1902:157, 321-328), daarna grotendeels vergeet en uiteindelik in 1920 gekanoniseer (Fabre, 1954:343).

In al drie gevalle is 'n deel van die vroue se marteling (hetsy fisies, hetsy sielkundig) die feit dat die regsproses hulle nie gunstig gesind was nie, aangesien hulle gemarginaliseerd was en teen alle norme en waardes in grense oorskry het. Die heilige Barbara is gemartel ná 'n verhoor deur die provinsiale prefek, omdat sy haar tot die Christelike geloof bekeer het (dus 'n grens oorgesteek het) en geweier het om afstand te doen van haar geloof (Kirsch, 2007). Artemesia Gentileschi is gemartel in 'n poging om Tassi skuldig te bevind, maar omdat dit ongewoon was dat vroue gewilde lede van die kunsgemeenskap van verkragting aankla en omdat sy self iets so "onvrouliks" gedoen het soos skilder, kon sy geen steun kry nie. Indien 'n mens kwessies soos omgang met demone en kettery ter syde stel, is die heilige Jeanne d'Arc skuldig bevind omdat sy haar nie gehou het by die kerklike leer van die tyd nie, mansklere gedra het en soos 'n man oorlog gevoer het (vgl. Fabre, 1954:290 e.v.; Murray, 1902.). Om sake te vererger het sy ook die verkeerde politieke affiliasies gehad in die oë van die hof wat haar verhoor het.

Wanneer die heilige Barbara, Artemesia Gentileschi en die heilige Jeanne d'Arc ter sprake is, is die kwessie van pyn en marteling dus sterker op die voorgrond as wanneer daar verwys word na die heilige Teresa van Avila, hoewel sy nouliks 'n gemaklike lewe gelei het. Dit wil egter nie voorkom of Viljoen/Winterbach dit aanbied as "[g]eëstetiseerde pyn" (Viljoen, 1993:142) nie. Dit is slegs in Artemesia Gentileschi se geval waar 'n geromantiseerde beeld van haar lewe deur Fonny Alexander aangebied word, maar dit word gebalanseer deur kommentaar van haar vriende, Bennie Potgieter en Ester Zorgenfliess. Ester "wys Fonny nie summier daarop dat sy van haar kop af is nie" (Winterbach, 1999:50), maar aangesien die leser gebeure deur haar oë ervaar, temper haar kommentaar Fonny se byna ekstatiese geesdrif vir 'n lydensweg. Daar kan dus nie sprake daarvan wees dat Viljoen/Winterbach 'n estetika van pyn bedryf deur haar verwysings na martelaarfigure nie. Sy plaas eerder die klem op die figuur self, as op die marteling. Dit blyk duidelik uit die terloopse verwysings na die heilige Jeanne d'Arc en die heilige Barbara. Hierdeur opper sy wel die onderwerp van marteling, veral binne die religieuse raamwerk, sonder om egter skuldig te wees aan "erotic fascination" (Coetzee, 1992:365), óf "a questionable dark 
lyricism" (Coetzee, 1992:366). 9 Sy vermy ook die risiko van 'n stereotipiese uitbeelding van sowel die martelaar as die gemartelde.

Viljoen/Winterbach bevind haar nie meer in die "óf ... óf"-situasie waarna Coetzee (1992:368) verwys nie, maar skep vir haarself 'n alternatief. Behalwe in die geval van Artemesia Gentileschi, is haar tegniek om die verwysings na historiese martelaars bondig te hou sodat die leser self die inkleding van die figuur moet behartig Viljoen/Winterbach skets slegs 'n buitelyn. Die terloopsheid van die verwysings (veral na 'n relatief obskure figuur - binne die SuidAfrikaanse konteks - soos die heilige Barbara) skep ook die indruk dat die leser weet na wie sy verwys, dat die leser onmiddellik die verwysing en die konnotasies wat die verwysing moet oproep, sal begryp. Viljoen/Winterbach vermy die slaggate waarna Coetzee (1992) verwys deur die leser self verantwoordelik te maak vir 'n representasie van die figuur. Uit haar werk (nie noodwendig die konteks waarin die verwysing verskyn nie, maar die prosateks as geheel) blyk dit egter in watter rigting sy die leser se interpretasie wil stuur. Die aard van hierdie interpretatiewe rigting sal hieronder bespreek word.

\subsection{Beheer oor liggaam en gees}

Die enigste manlike heilige en mistikus wat Viljoen/Winterbach in haar werk betrek, is die heilige Ignatius Loyola, die stigter van die Jesuïete. Hy word slegs drie maal in Landskap met vroue en slang genoem en in al drie gevalle is daar sprake van sy "spirituele oefeninge" (Viljoen, 1996:15, 81 en 82) waardeur 'n "suiwering van die siel" (Viljoen, 1996:82) bewerkstellig word. Die heilige Ignatius Loyola word dus in Viljoen/Winterbach se werk gekenmerk deur pogings om sy siel te suiwer en sy liggaam te beheer, in teenstelling met die vroulike mistici en geestelikes wat visioene het en deur ander persone gedwing word om op 'n bepaalde wyse op te tree. Verder verskil Loyola se geskiedenis ook van dié van die vroulike mistici en geestelikes. Waar die vroue almal (na bewering) maagde was, met die uitsondering van Artemesia Gentileschi, wat verkrag is, het Loyola voor sy "spirituele ontwaking" moreel gesproke nie 'n blaamlose lewe gelei nie (Marcuse, 1939:47; Sedgwick, 1923:2). Vir hom was spirituele suiwerheid dus van besondere belang, omdat sy

9 Die karakter Fonny Alexander trap wel in hierdie slaggat. Sy sien in haar eie wedervarings parallelle met die lewe van Artemesia Gentileschi en kry klaarblyklik 'n mate van genoegdoening uit haar selfopgelegde status as "martelaar". 
verlede altyd bygesleep sou kon word, indien hy op 'n manier sou optree wat deur die kerk bevraagteken kon word.

Deur die klem op Loyola se spirituele oefeninge te plaas, suggereer Viljoen/Winterbach moontlik dat mans groter klem moet plaas op die beheersing van hulle liggaamlike behoeftes en keer sy só die tradisionele assosiasie van manlikheid-rasionaliteit en vroulikheid-liggaamlikheid ten volle om. By die vroulike mistici en geestelikes is daar nie sprake van spirituele suiwering nie, hoewel hulle ongetwyfeld na spirituele suiwerheid gestreef het. Daar is ook nie sprake van die ontberings wat hulle beleef het nie, behalwe by die verwysings na Artemesia Gentileschi. Ignatius Loyola se "spirituele tegnieke" word selfs direk gekontrasteer met Artemesia Gentileschi se benadering tot kuns en die lewe ná haar verkragting (Viljoen, 1996:81). Hierdie kontras sal later weer ter sprake kom wanneer die mistisisme van die meester in Landskap met vroue en slang met Fonny Alexander se mistisisme gekontrasteer word.

Deur die leser se aandag op die ekstatiese en pynlike bestaan van vroulike mistici te vestig en die beheersde lewenswyse van die heilige Ignatius Loyola, vestig Viljoen/Winterbach óók die leser se aandag op die feit dat die spelreëls wat deur die sentrum opgestel word - die dominante gedragskodes - nie noodwendig konsekwent is of konsekwent toegepas word nie. Sy suggereer ook moontlik dat teenoorgestelde spelreëls binne die marge en binne die sentrum geld.10 As man kon die heilige Ignatius Loyola in die teenswoordige wêreld sy drifte uitleef omdat hy deel van die maghebbende groep was. Binne die wêreld van die monastiese orde kon hy egter net tot die sentrum van daardie orde deurdring indien hy sy siel "suiwer" en juis besonder baie selfbeheersing aan die dag lê. In hierdie opsig blyk die marge 'n spieëlbeeld te wees van die sentrum. Dit word ook duidelik dat die marge nie 'n sone is waar algehele chaos heers nie. Binne die marge is ook magstrukture, magsentra en spelreëls. In die volgende afdeling sal dit duidelik word dat hierdie magstrukture, magsentra en spelreëls binne die marge dikwels deur die sentrum

10 Dit is natuurlik 'n oop vraag of die monastiese ordes in die Middeleeue werklik as deel van die marge gesien kon word vanweë hulle politieke en sosiale mag. Die Jesuïete was veral in Spanje 'n belangrike groepering. Hoewel die praktyk radikaal anders was, was die monastiese ordes egter veronderstel om nie hulself met die teenswoordige wêreld te bemoei nie en om hulself aan kontemplasie en naastediens te wy. As gevolg hiervan word die monastiese ordes as deel van die marge gesien. 
gegenereer word en dat pogings tot bemagtiging binne die marge soms in weklikheid 'n proses van ontmagtiging is.

\section{Karakters as mistici}

Karakters wat as mistici of geestelikes beskou kan word, kan geanaliseer word deur hulle te vergelyk met die raamwerk van werklike mistici, soos in die vorige afdeling beskryf is. Hierdie raamwerk bestaan uit potensieel ondermynende liggaamlike ervarings, pyn en martelaarskap en (rasionele) beheer oor die liggaamlike in 'n poging om die siel te suiwer. So 'n raamwerk moet egter nie as 'n bloudruk vir karakters se optrede gesien word nie, maar eerder as 'n patroon waarmee karakters se dade en woorde vergelyk kan word.

\subsection{Mistieke ervarings}

Dit is insiggewend dat die twee karakters wie se mistieke ervarings die meeste aandag geniet, 'n bruin vrou en 'n kind is en dat albei van hulle in Buller se plan verskyn: Fonny Alexander en Boetie Kareltjie. Albei kan as gemarginaliseerd beskou word. Fonny Alexander, omdat sy onder die apartheidsregime deur middel van wette uit die sentrum gehou is en klaarblyklik tydens die nuwe bedeling steeds nie ten volle toegang tot die sentrum het nie, ten dele omdat sy ' $n$ vrou is, en ten dele vanweë haar ras. Binne tradisionele Afrikanergesinne het volwassenes toegang tot die magsentrum; kinders word egter mag ontsê.11 Boetie (Oompie) Karel(tjie) se ouderdom belet hom toegang tot die sentrum, al is hy wit en manlik. Aangesien hy klaarblyklik tot 'n Afrikaanse familie behoort wat tydens die SuidAfrikaanse Oorlog deur die Britse regime ontmagtig is (Winterbach, 1999:27), behoort hy, ten minste ten tyde van sy mistieke ervarings, tot die marge.

'n Tweede belangrike punt oor albei karakters is die wyse waarop hulle mistieke ervarings ooreenkom. Hulle fisieke gedrag tydens die ervaring word aan dié van 'n dier gelyk gestel: sowel Fonny as Boetie Karel staan hande-viervoet (Winterbach, 1999:60, 166) soos

11 Hiermee word nie bedoel dat daar nie by kinders 'n magshiërargie is nie. Binne die patriargale tradisie van sowel Afrika as die Weste het manlike kinders meer mag as vroulike kinders, wit kinders het meer mag as swart of bruin kinders, kinders uit hoër sosio-ekonomiese strata het mag oor kinders uit laer klasse, ensovoorts. Teenoor volwassenes (en definitief teenoor volwassenes van dieselfde ras) het kinders egter oor die algemeen betreklik min mag, hoewel magsverhoudings gekompliseer word deur verskille in ras, geslag en klas tussen die kind en die volwassene. 
'n dier (Winterbach, 1999:57, 166). Daar is ook ander elemente in veral Fonny se mistieke ervarings. Dit is insiggewend dat daar tydens Fonny se ervarings geen kwessie van kalmte of meditasie is nie, maar eerder 'n ontmensliking. Dit kontrasteer baie sterk met die geestelikheid van die meester wat later bespreek sal word. Hierdie ontmensliking is 'n proses wat Fonny deurmaak in die loop van die roman en waarna weer verwys sal word.

Boetie Karel(tjie) se mistieke ervarings toon sterk ooreenkomste met dié van Fonny. Daar word egter aansienlik meer inligting oor Fonny se ervarings gegee en ook kommentaar gelewer op haar en haar mistieke ervarings - veral deur Ester Zorgenfliess en Bennie Potgieter. Die keuse van kommentators is van belang. As buitestander in die dorp Steynshoop, is Ester nie direk betrokke by enige van die gebeure nie en sy tree dikwels as waarnemer op en nie as deelnemer nie. Sy verkeer telkens op die rand van gesprekke en gebeure en het daarom, ten minste binne Steynshoop, marginale status. Bennie Potgieter, daarenteen, is een van Fonny se goeie vriende (Winterbach, 1999:75) en meer nog:

Bennie bly tog vir 'n groot deel op die dorp, hy is dikwels [daar] ... hy moet baie kontakte [daar] hê, soos [Daan] vir Bennie ken, sal hy presies weet wat in die dorp aangaan, en in die omgewing, en in die stad, en in die hele land, en nog buite die land ook. Niks, wat die moeite werd is, sê Daan, ontglip ooit Bennie se aandag nie ... 'n Medewerker in elke hawe, sê Stefan ... die ou is nogal uncanny, en saam met Jonah Voorsanger het hulle seker maklik 'n vinger op elke pols; 'n kontakpersoon in elke stad (Winterbach, 1999:136).

Deurdat Ester en Bennie kommentaar lewer op Fonny, kry die leser sowel 'n buitestander as 'n binnestander se perspektief op gebeure; dus sowel 'n perspektief uit die marge as 'n perspektief uit die sentrum. Dit is veral laasgenoemde perspektiewe wat van belang is, aangesien dit wil voorkom asof Bennie se posisie binne die sentrum deurslaggewend is in sy oordeel oor Fonny se mistieke ervarings en haar dade.

Wat insiggewend is omtrent Fonny se ervarings van 'n eenwording met God, is dat dit gewoonlik geskied wanneer sy een of ander trauma beleef, veral traumas wat om mans sentreer. Sy het vir die eerste keer in jare 'n mistieke ervaring nadat sy alleen 'n nag in die blokhuis deurgebring het (Winterbach, 1999:57). Sy isoleer haarself daar vanweë ' $n$ byna moorddadige aanval op haar deur twee mans, 'n aanval wat plaasgevind het met die medewete (of selfs in opdrag) 
van haar eertydse vriend, Petrus (Winterbach, 1999:50). Hierdie ervaring was die eerste sedert haar tienerjare, toe sy 'n "paar keer baie intense ervarings gehad het" (Winterbach, 1999:94) nadat haar pa verdwyn het; "[d]ie eerste keer sedert sy 'n jong kind was" (Winterbach, 1999:94). In albei gevalle is Fonny se mistieke ervarings dus 'n manier om die trauma te verwerk en haarself te oortuig dat sy bemind is. In die ervaring(s) na die aanranding is daar ook 'n erotiese komponent aanwesig - soos duidelik blyk uit haar beskrywing daarvan (Winterbach, 1999:57). In 'n bepaalde opsig is dit egter 'n veilige tipe erotiek: die man, die persoon wat verantwoordelik was vir haar trauma, is verwyder uit die ervaring; sy beleef ' $n$ eenwording met die godheid waartydens die erotiese ervaring spiritueel is en nie fisiek nie.

Fonny se ervarings voldoen nie net aan die erotiese aspek van die raamwerk van mistieke ervarings wat reeds beskryf is nie, maar dit is blykbaar ook 'n poging om mag te verkry. Haar ervarings plaas haar op 'n meer verhewe vlak as Petrus wat uit jaloesie die aanval op haar gereël het, aangesien sy, na haar eie mening, deur God uitgekies is om sodanige ervarings te beleef. Binne ' $n$ religieuse opvatting weeg 'n posisie nader aan die godheid swaarder as een nader aan 'n bron van fisieke (gewelddadige) krag wanneer dit kom by die bepaling van 'n magsentrum. Fonny se hunkering na mistieke ervarings lei egter daartoe dat sy binne die teenswoordige wêreld (al is dit dan ook die teenswoordige wêreld soos uitgebeeld in 'n roman) ontmagtig word. Ten dele kom hierdie ontmagtiging na vore wanneer sy aan Ester vertel dat sy, as gevolg van haar mistieke ervarings, tekort skiet en "tot sterwens toe alleen" voel (Winterbach, 1999:58). In 'n poging om meer gereeld mistieke ervarings te beleef, wil sy

... in 'n blokhuis uit die Anglo-Boereoorlog in die middel van die veld ... gaan woon - omdat dit waarskynlik strook met een of ander idee wat sy het van 'n lewe in volslae afsondering sodat sy altyd in volkome gereedheid kan wees vir haar ontmoetings met God (Winterbach, 1999:86).

Hierdie onttrekking uit die samelewing het byna die teenoorgestelde impak as wat dit tydens die Middeleeue vir vroue gehad het. Tydens die Middeleeue was 'n soortgelyke onttrekking uit die samelewing een manier waarop vroue wel 'n mate van mag kon bekom, ten minste oor hulle eie liggame, en waarop hulle ten dele vir hulself 'n stem kon bewerkstellig. Fonny se onttrekking uit die gemeenskap van Steynshoop gaan gepaard met die vernietiging van al haar kunswerke. Ironies genoeg is dit haar kuns, waarvoor sy na skool "voluit" 
(Winterbach, 1999:94) geleef het, wat haar 'n tyd lank gered het (Winterbach, 1999:94). In 'n poging om meer mistieke ervarings te beleef, vernietig Fonny dit wat haar kon help om haar trauma te verwerk, dit wat haar die geleentheid kon gee om kommentaar te lewer op die samelewing waarin sy haarself bevind en dit wat haar die moontlikheid gegee het om grense te oorskry (sowel fisies as sosiaal). Fonny vernietig sodoende haar stem en verseker dat sy in 'n gemarginaliseerde posisie bly. Die enigste geleentheid wat sy het om grense oor te steek, is binne 'n religieuse raamwerk.12 Fonny is dus besig met ' $n$ proses van selfontmagtiging en 'n stroping van haar eie identiteit. Tussen haar mistieke ervarings bevind sy haarself in 'n grys woestyn (Winterbach, 1999:128) waarin sy "[u]itwissing ... vrees" (Winterbach, 1999:129), nie kan slaap nie en ook nie wakker kan wees nie (Winterbach, 1999:129). In hierdie toestand is haar "gees ... in verwarring en [in] donkerte gedompel" (Winterbach, 1999:161). Fonny se liminaliteit is dus baie beperk in die sin dat sy 'n geestelike grens kan oorsteek, maar dat sy nie sélf bepaal wanneer hierdie grens oorgesteek word of op watter manier dit oorgesteek word nie; sy kan nie self die aard en tydstip van die grenservaring bepaal nie. Die religieuse raamwerk waarbinne sy funksioneer, gun haar nie soveel moontlikhede vir grensoorskryding nie en die proses van grensoorskryding lei nie tot enige wesenlike ondermyning van die sosiale orde nie, maar eerder tot 'n ondermyning van die self.

Van deurslaggewende belang in Fonny se mistieke ervarings, is dat sy haarself as ' $n$ martelaar sien (Winterbach, 1999:44, 95). Sy is gewillig om te ly aangesien dit deel uitmaak van haar eenwording met God. Fonny identifiseer duidelik baie sterk met Artemesia Gentileschi. Ironies genoeg het Gentileschi se kunstenaarsloopbaan eers werklik begin ná haar verkragting en die hofsaak teen Tassi, terwyl die aanval op Fonny juis die einde van háár loopbaan as kunstenaar beteken. Dit is 'n aanduiding dat Fonny nie identifiseer met Gentileschi as kunstenaar nie, maar eerder met Gentileschi as vrou wat deur mans en die patriargale stelsel geweld aangedoen is. Sy fokus telkens op die "bloed van martelare" (Winterbach, 1999:44, 95), wat blykbaar vir haar as 'n simbool van pyn en lyding dien ter wille van 'n spesifieke oortuiging.

12 Dit moet onthou word dat 'n tradisionele Christelike raamwerk nie besonder goedgesind was (is) teenoor vroue nie, soos wat Jantzen (1997:43) aandui. 
Fonny se proses van self-isolasie, gekoppel aan haar oënskynlike waansin en haar religiositeit, toon ooreenkomste met die relatief algemene skisofrenie in Wes-lerland wat Nancy Scheper-Hughes (2001) bespreek. Scheper-Hughes probeer die bogemiddelde voorkoms van skisofrenie in Wes-lerland koppel aan 'n repressiewe lewenswyse wat deur die morele dogmas van die Rooms-Katolieke Kerk veroorsaak word en ook deur 'n tradisie van onttrekking en afsondering wat deur die vroeë missionarisse gevestig is (ScheperHughes, 2001:169). Sy lê 'n verband tussen Westerse samelewings en "many non-western and so called primitive societies" waar

... the symptoms of life-crisis 'reactive' schizophrenias are often identified with religious conversion of mystical experience, and the individual may be elevated to the role of prophet or shaman (Scheper-Hughes, 2001:145).

In die Weste van lerland (veral County Kerry)

... the high rates for long-term occupancy of mental hospital beds might also be examined within the historical and cultural context of the retreat to isolation and confinement, particularly during periods of stress and cultural distortion. The 'search for asylum' in County Kerry can be witnessed in the history of the primitive monk cells of Sceilig Mhichil and Mount Brandon ... and in the great stone monstrosity of the county mental hospital itself (Scheper-Hughes, 2001:169; kursivering - LF).

Fonny se onttrekking uit die gemeenskap van Steynshoop, gekoppel aan die hernuwing van haar mistieke ervarings, sou dus nie alleen geïnterpreteer kon word as skielike religieuse waansin nie, maar ook as 'n poging om die aanval wat sy oorleef het, te verwerk. Fonny Alexander se geval is ook 'n goeie aanduiding van die dun skeidslyn tussen mistieke ervarings en sielkundige onstabiliteit.

Klaarblyklik is Ester die enigste karakter binne Fonny se vriendekring wat werklik besorg is daaroor dat sy haarself doelbewus marginaliseer. Hoewel "Jonah-hulle" aanvanklik aandring dat Fonny 'n klag teen Petrus indien (Winterbach, 1999:95), toon niemand uit daardie betrokke kring besondere belangstelling in Fonny se verdere doen en late nie. Dit is slegs die vroue in die Steynhuis wat ontstig is deur die feit dat Fonny al haar kunswerke verbrand het (Winterbach, 1999:86). Bennie Potgieter, wat oënskynlik een van Fonny se vriende is en wat meer weet omtrent haar situasie as die vroue in die Steynhuis, lyk egter nie besonder bekommerd oor Fonny nie. Hy sê aan Ester dat Fonny "daarop aandring om haar ervaring [...] binne die raamwerk van 'n powerful patriargale meta- 
foor aan te bied" (Winterbach, 1999:112), dat "[e]lke metafoor sy eie reëls en wetmatighede" het (Winterbach, 1999:75), maar dat Fonny veilig is "[b]inne die terme van haar eie metafoor" (Winterbach, 1999:75). Bennie intellektualiseer dus Fonny se posisie en aanvaar dat sy weet wat sy doen (Winterbach, 1999:111-112), ten spyte van die feit dat sy duidelik deur die aanval op haar getraumatiseerd is. In hierdie opsig verteenwoordig Bennie juis die patriargale bestel wat rasionele optrede te alle tye voorhou as 'n toelatingsvereiste tot die sentrum.

Anders as Bennie, is Ester nie so geneë daarmee om Fonny se selfmarginalisering te aanskou nie. Wanneer Fonny aankondig dat sy haar werk verbrand het en in die blokhuis gaan bly, voel Ester dat "Fonny ... van haar kop af is", "van haar verstand af" en "haar gesonde verstand kwyt [is] na die aanval" (Winterbach, 1999:50). Ester erken dus ook, soos Bennie, dat Fonny haar lewe probeer lei binne 'n raamwerk van religieuse metafore, dat die "verhaal" van die martelaar die "verhaal" is waarvolgens Fonny haar lewe lei (vgl. Winterbach, 1999:129). Net soos Bennie, sien Ester ook Fonny se optrede as 'n manier om haar trauma te verwerk. Anders as Bennie, sien sy dit egter nie as die gevolg van 'n rasionele besluit nie, maar eerder as sielkundige onstabiliteit. Bennie aanvaar blykbaar dat Fonny op 'n rasionele wyse tot 'n slotsom gekom het en dat haar optrede doelbewus en vooraf bepland is. Ester sien Fonny se optrede egter as 'n ontsporing vanweë haar trauma - 'n ontsporing waaroor sy nie besonder baie beheer het nie.

Waar die aanklag van "malheid" sedert die negentiende eeu gebruik is om ongewenste persone uit die samelewing te verwyder (vgl. Foucault, 2003), is daar sedert die sewentigerjare van die twintigste eeu beweer dat "malheid", ten minste by vroue, gelees kan word as 'n simbool van die ondermyning van die patriargale bestel.13 Marta Caminero-Santangelo (1998:125) redeneer egter dat sielkundige onstabiliteit die illusie van mag skep, terwyl dit werklik net 'n simboliese oplossing is wat uiteindelik tot groter magteloosheid lei. Ester sien

In projecting their anger and dis-ease [sic] into dreadful figures, creating dark doubles for themselves and their heroines, women writers are both identifying with and revising the self-definitions patriarchal culture has imposed on them [...] Such a radical misreading of patriarchal poetics frees the woman artist to imply her criticism of the literary conventions she has inherited even as it allows her to express her ambiguous relationship to a culture that has not only defined her gender but shaped her mind. 
klaarblyklik in dat Fonny se mistieke ervarings en onttrekking uit die samelewing nie (slegs) 'n doelbewuste keuse deur Fonny is nie, maar dat dit saamhang met samelewingsverskynsels wat die aanval op haar moontlik gemaak het, en dit ook vir haar moontlik maak om haarself te marginaliseer deur middel van religieuse oortuigings (vgl. Caminero-Santangelo, 1998:125).

Ironies genoeg is Fonny se pogings om aan 'n gewelddadige patriargale stelsel te ontsnap deur middel van mistisisme, slegs 'n voortsetting van daardie patriargale stelsel binne 'n ander raamwerk. Sy slaag slegs daarin om haarself verder te marginaliseer en om haar eie ondermynende stem (vgl. Winterbach, 1999:86, 112) stil te maak. Fonny se mistisisme-as-ontsnapping kontrasteer met die mistisisme van die meester in Landskap met vroue en slang wat in die volgende onderafdeling aan bod sal kom.

\subsection{Beperking van gehegtheid}

Beskrywings van die meester se mistisisme in Landskap met vroue en slang bevat elemente wat herinner aan dié van die heilige Ignatius Loyola en van Jess, 'n aanhanger van die Zen-Boeddhisme, in Karolina Ferreira. In den brede verskil die meester se mistisisme op twee punte van Fonny s'n. Eerstens is dit nie iets wat in isolasie beoefen word nie; daar is nie 'n permanente onttrekking uit die samelewing nie. Tweedens wil dit voorkom asof daar nie hoogtes en dieptes van dieselfde uiterstes is as wat Fonny ervaar nie.

Daar is egter ook ooreenkomste tussen die meester en Fonny en dit is raadsaam om eers daaraan aandag te skenk voordat daar na die (beduidende) verskille gekyk word. Net soos Fonny, lyk dit asof die meester 'n buitestander is. Die inligting wat die leser oor die meester kry, word aangebied in 'n aantal hoofstukke waar Lena en Jack hulle aansluit by 'n groep mense op 'n plaas in die Karoo. Die meester is Hongaars (Viljoen, 1996:144, 157) en lyk gevolglik nie ten volle tuis in die Karoolandskap nie - in hierdie opsig sou hy as marginaal beskryf kon word. Dit wil voorkom asof hy nie graag sosiaal met die groep mense in die huis meng nie (Viljoen, 1996:147), net soos wat Fonny haar toenemend uit die sosiale wêreld van die Steynhuis verwyder. Hy is ook, net soos Fonny, op soek na "verligting". Binne Fonny se religieuse raamwerk beteken die term egter iets anders sy soek eerder verligting van die grys gebied tussen mistieke ervarings.

Hulle benadering tot mistieke ervarings is egter baie verskillend. Waar die klem gedurig op Fonny se passiwiteit en die wegkalwering 
van haar identiteit is, is die meester baie meer aktief in sy soeke na verligting: hy "sing ... sag op een toon of mediteer; slyp sy gees steeds skerper" (Viljoen, 1996:146). Hy "duld geen nonsens" (Viljoen, 1996:145) wanneer dit kom by die opheffing van slegte gewoontes nie (Viljoen, 1996:144). Sy optrede herinner aan die heilige Ignatius Loyola se "spirituele oefeninge" (Viljoen, 1996:15, 81, 82) wat bedoel was om die siel te suiwer en die liggaam meer onder die beheer van die (rasionele) denke te plaas. ${ }^{14}$ Hierdie beheer oor die mistieke ervaring is die teenoorgestelde van Fonny se onvoorspelbare, eroties-gelade ervarings.

Die meester is ook tussen mense. Hy was klaarblyklik een van vele dissipels van die "geliefde vorige meester" (Viljoen, 1996:145) en die onderrig wat hy gee, geskied sowel individueel as in groepsverband (vgl. Viljoen, 1996:144, 148). Die atmosfeer op die plaaswerf herinner besonder sterk aan 'n kommune. Hy sonder hom wel van tyd tot tyd af, maar dit wil nie voorkom of sy mistieke belewings daarop berus dat hy in isolasie moet wees nie, anders as wat met Fonny die geval is.

Die belangrikste verskil tussen die meester (en sy mistisisme) en Fonny (en háár mistisisme) is dat verligting (in die Zen-Boeddhistiese tradisie) kan geskied as gevolg van iets absurds, nie as gevolg van eenwording met die godheid nie. Een van die vorige meester se dissipels, mevrou Tanaka, verkry verligting omdat sy gelag het vir die absurditeit van die vorige leermeester se woorde en dade (Viljoen, 1996:148) en omdat sy klaarblyklik geleer het om haarself, diegene om haar én haar geestelike lewe nie so ernstig op te neem nie. By die meester is daar dus baie duidelik tekens van die ondermynende karnevaleske lag (vgl. Bakhtin, 1994:200 e.v.) wat geheel en al afwesig is by Fonny (wie se mistisisme slegs vir haarself ondermyn). Fonny verbind haar mistieke ervarings met die bloed van martelare; die meester verbind syne aan "'n helse, ongelooflike poep" (Viljoen, 1996:148).

Terselfdertyd is die meester se mistisisme nie een van gedurige belaglikhede nie, maar eerder oorwegend rigtinggewend van aard. $\mathrm{Hy}$ wil hê Lena moet die slegte gewoontes van meer as veertig jaar breek (Viljoen, 1996:144). Hy raai haar aan om te leer uit situasies

14 Die groot kulturele verskil is natuurlik dat rasionaliteit vir Loyola, binne die Westerse tradisie aan die einde van die Middeleeue, van groot belang sou wees terwyl die meester, as Zen-Boeddhis, waarskynlik nie veel gemoeid sou wees met rasionele denke nie. 
wat sy nie kan vermy nie (Viljoen, 1996:148) en om nie geheg te raak aan die verlede nie (Viljoen, 1996:148). Later vind die leser uit dat hy ook iets oor pyn gesê het (Viljoen, 1996:153). Dit wat die meester aan Lena oordra, toon sterk ooreenkomste met die Boeddhisme. Tesame met die idee van onthegting is daar die konsep van onmiddellikheid, van onverdeelde aandag (Viljoen, 1996: 173) vir die hier en nou - idees wat albei reeds in Karolina Ferreira in Jess en Karolina se gesprekke opgeduik het.

Wÿbenga (1995:103) voer aan dat "'n sekere passiwiteit, voorwaarde [is] vir die mistieke belewenis". 'n Mate van passiwiteit kenmerk inderdaad sowel die meester se mistisisme as dié van Fonny. Passiwiteit word gewoonlik as 'n vroulike eienskap gesien: daar word oor die algemeen in patriargale samelewings verwag dat vroue passief en ontvanklik sal wees, nie alleen tydens die geslagsdaad nie, maar te alle tye. Sowel die meester as Fonny se mistisisme sou dus "vroulik" genoem kon word en hierdie mistisisme sou gevolglik 'n teenvoeter kon wees vir die eng patriargale raamwerk waarin 'n mens slegs suksesvol kan wees indien jy aktief sekere doelwitte najaag. Fonny en die meester se mistisisme verskil egter in die wyse waarop die mistici sodanige passiwiteit ervaar en hanteer. Vir Fonny beteken passiwiteit lyding, binne die meesteragtige mistisisme is die oogmerk juis om lyding te ervaar, maar ook om nie daaraan vas te klou nie.

\section{Slotopmerkings}

Oor die algemeen wil dit voorkom asof die meester se mistisisme opgestel kan word teen die ekstreme estetika van pyn en ekstatiese eensaamheid wat Fonny beleef, omdat Fonny vasklou aan die pyn wat sy ervaar tydens haar mistieke belewenisse. Binne die Boeddhisme is daar gedurig ' $n$ strewe na die aflegging van begeerte; die "realization of absolute Nothingness is in Zen the realization of one's true Self" (Abe, 1986:187). ${ }^{15}$ Fonny verheerlik sowel haar lyding as

Voorts beweer Abe (1986:187):

Nothingness opens up the deepest ground of one's Subjectivity which is beyond every form of subject-object duality, including the so-called divine-human relationship. Enlightenment takes place only through the realization of absolute Nothingness which is beyond every form of duality. This is not faith in the divine mercy nor salvation by a divine, other power, but Self-Awakening - the Self-Awakening of the true Self.

Binne die kader van die Zen-Boeddhisme is ervarings soos Fonny s'n dus teenproduktief wat die bereiking van verligting betref. 
haar ekstase en beweeg sodoende gedurig van die een uiterste na die ander. Wanneer sy haar in die tussengebied bevind, vind sy haarself "in verwarring en [in] donkerte gedompel" (Winterbach, 1999:161). Dit is opmerklik dat al die eksponente van die meesteragtige mistisisme (die meester, Jess en Lena Bergh se eggenoot, Jack) mans is. Dit beteken nie dat die meester se tipe mistisisme beperk is tot mans nie, slegs dat die vernaamste eksponente van hierdie mistisisme mans is, terwyl 'n vrou die grootste eksponent van die ekstreme, liggaamlike mistisisme is. Aanvanklik wil dit voorkom asof Viljoen/Winterbach haar skuldig maak aan stereotipering. Hierdie verdeling moet egter gesien word in terme van mag: Fonny se mistisisme (so naby aan die malheid wat deur Gilbert en Gubar (1979) beskryf word) lei tot haar ontmagtiging. Die Middeleeuse vroulike mistici het ook deur middel van die ekstatiese eensaamheid en die estetika van pyn onder die waan verkeer dat hulle mag het, terwyl hulle in werklikheid nie mag gehad het nie. In die beste scenario's is hulle 'n beperkte mate van mag gegun, maar dit kon nooit vergelyk word met die mag wat mans binne die sentrum gehad het nie. Binne die meester se mistisisme kan enigeen verligting bereik - die fokalisators wat onderrig word, is almal vroue en daar word pertinent melding gemaak van hoe mevrou Tanaka verligting kry.

Dit lyk nie of Lena (of ook Karolina Ferreira onder leiding van Jess) konsekwent probeer om 'n Boeddhistiese of soortgelyke lewenswyse te handhaaf, óf konsekwent Boeddhistiese filosofieë aanhang nie. Op hierdie wyse word die mistisisme van die meester wel ondermyn en bevraagteken. Dat Lena wel kontak het met die meester (oënskynlik as leerling) dui egter aan dat die meester se mistisisme voorkeur geniet bo iets soos Fonny s'n, in die lig van die afkeur wat daaroor uitgespreek word deur Ester Zorgenfliess. Daar kan dus geargumenteer word dat Viljoen/Winterbach effe ambivalent daaroor is dat haar karakters "lig en aandagtig" (Viljoen, 1996:9) deur die lewe reis, maar terselfdertyd is daar 'n baie duidelike afkeur vir Fonny se intense ervarings wat haar, tússen ervarings, in 'n grys waas laat waarin sy kwalik bestaan. Dit sou moontlik wees om hierdie logika tot die uiterste te voer en te redeneer dat Viljoen/ Winterbach die Boeddhisme as leer bo die Christendom verkies, maar vir so 'n kru vereenvoudiging is Viljoen/Winterbach se werk oor die algemeen gans te genuanseerd. ' $n$ Beter stelling sou wees dat die meester se mistisisme nie die ervaring van pyn, lyding en skuldgevoelens tot 'n deug verhef nie en sodoende nie 'n mistisisme van martelaarskap is nie. Daarteenoor is Fonny se mistisisme duidelik een van selfopgelegde martelaarskap waartydens lyding byna fetisjistiese proporsies 
aanneem. Hierdie mistisisme lê haar uiteindelik lam en stroop haar van haar identiteit. Die meester se mistisisme stel hom beter in staat om grense te kruis as wat Fonny se mistisisme haar toelaat om te doen. Sy is klaarblyklik vasgevang binne 'n begrensde gebied waarvan sy geeneen van die grense kan oorsteek nie.

\section{Geraadpleegde bronne}

ABE, M. 1986. Zen and Western thought. Ed. by William R. LaFleur. Houndmills: Macmillan.

BADER, D. 2005. One hundred great books in Haiku. London: Viking.

BAKHTIN, M. 1994. The Bakhtin reader: selected writings of Bakhtin, Medvedev and Voloshinov. Ed. by Pam Morris. London: Arnold.

BOTHA, E. 1995. "Die spel word telkens in die tyd herhaal": gedaantes van vernuwing in die Afrikaanse letterkunde. Stilet, 7(2):1-10.

CAMINERO-SANTANGELO, M. 1998. The madwoman can't speak: or why insanity is not subversive. Ithaca: Cornell University Press.

COETZEE, J.M. 1992. Into the dark chamber: the writer and the South African State. (In Atwell, David, ed. Doubling the point: essays and interviews. Cambridge: Harvard University Press. p. 361-368.)

CONCISE OXFORD ENGLISH DICTIONARY. 2002. 10th ed. Oxford: Oxford University Press.

FABRE, L. 1954. Joan of Arc. Translated from the French by Gerard Hopkins. London: Odhams.

FELLEMAN, S. 2001. Dirty pictures, mud lust and abject desire: myths of origin and the cinematic object - art and artists in the movies. Film quarterly, Fall. http://www.findarticles.com/p/articles/mi_m1070/is_1_55/ai_ 80225750 Date of access: 30 Aug. 2004.

FOUCAULT, M. 2003. Madness and civilization: a history of insanity in the age of reason. Translated by Richard Howard. London: Routledge.

GARRARD, M.-D. 1989. Artemesia Gentileschi: the image of the female hero in Italian baroque art. Princeton: Princeton University Press.

GILBERT, S.M. \& GUBAR, S. 1979. The madwoman in the attic: the woman writer and the nineteenth-century literary imagination. New Haven: Yale University Press.

JANTZEN, G.M. 1997. Power, gender and Christian mysticism. Cambridge: Cambridge University Press.

KIRSCH, J.P. 2007. The Catholic encyclopedia. Online edition. http://www. newadvent.org/cathen/02284d.htm Date of access: 10 Feb. 2008.

MARCUSE, L. 1939. Soldier of the church: a life of Ignatius Loyola. Translated from the German and edited by Christopher Lazare. London: Methuen.

MURRAY, T.D., ed. 1902. Jeanne D'Arc: maid of Orleans, deliverer of France: being the story of her life, her achievements, and her death, as attested on oath and set forth in the original documents. London: Heinemann.

OPFELL, O.S. 1991. Special visions: profiles of fifteen women artists from the Renaissance to the present day. Jefferson: McFarland.

SCHEPER-HUGHES, N. 2001. Saints, scholars and schizophrenics: mental illness in rural Ireland. 20th ed. Berkele: University of California Press.

SEDGWICK, H.D. 1923. Ignatius Loyola: an attempt at an impartial biography. London: Macmillan. 
VILJOEN, L. 1993. Karolina Ferreira. Kaapstad: Human \& Rousseau.

VILJOEN, L. 1995. Disrupsie en appropriasie in Lettie Viljoen se Karolina Ferreira. Stilet, 7(2):32-45.

VILJOEN, L. 1996. Landskap met vroue en slang. Kaapstad: Human \& Rousseau.

WINTERBACH, I. 1999. Buller se plan. Kaapstad: Human \& Rousseau.

WŸBENGA, G. 1995. Karolina Ferreira (Lettie Viljoen); of, Mot - metamorfose mistiek. Tydskrif vir letterkunde, 33(1):102-106.

\section{Kernbegrippe:}

Ingrid Winterbach

martelaar

mistisisme

vroulikheid

\section{Key concepts:}

femininity

Ingrid Winterbach

martyr

mysticism 